\title{
RANCANG BANGUN SISTEM KONTROL KECEPATAN DAN KETEPATAN PENGHENTIAN PROSES PENGELASAN PADA PROSES PENGELASAN PIPA
}

\author{
Candra Dwi Cahyono \\ Fakultas Teknik, Program Studi Teknik Mesin \\ Universitas Muria Kudus \\ Email: candradwicahyono.cdc@gmail.com \\ Qomaruddin \\ Fakultas Teknik, Program Studi Teknik Mesin \\ Universitas Muria Kudus \\ Email: qomaruddin@umk.ac.id \\ Hera Setiawan \\ Fakultas Teknik, Program Studi Teknik Mesin \\ Universitas Muria Kudus \\ Email: hera.setiawan@umk.ac.id \\ Akhmad Zidni Hudaya \\ Fakultas Teknik, Program Studi Teknik Mesin \\ Universitas Muria Kudus \\ Email: akhmad.zidni@umk.ac.id
}

\begin{abstract}
ABSTRAK
Proses pengelasan melingkar banyak dijumpai pada proses manufaktur di dunia industri seperti proses pengelasan pada rangka berbentuk pipa, tabung tekan, pipa distribusi dan lain-lain. Pada proses pengelasan melingkar secara manual sering kali ditemukan cacat las karena adanya kesulitan pengelasan pada bidang yang melingkar. Untuk mengatasi permasalahan ini, perlu dibuat alat bantu pemutar benda kerja pada proses pengesahan dan dapat diatur kecepatannya. Tujuan dari penelitian ini adalah melakukan rancang bangun sistem kontrol urutan proses, kecepatan dan ketepatan penghentian proses pengelasan pada proses pengelasan pipa. Metodologi penelitian ini dimulai dengan kajian pustaka, analisa kebutuhan sistem kontrol, desain sistem kontrol, pembuatan dan pengujian alat. Sebagai hasil, peralatan bantu proses pengelasan pada benda kerja yang melingkar telah berhasil dibuat. Beberapa parameter proses manufaktur dapat ditampilkan dalam LCD. Kecepatan pengelasan benda kerja pada tampilan LCD dibandingkan dengan pengujian dengan tacho meter mempunyai persentase kesalahan berturut-turut berkisar $1,5 \sim 1,7 \%$ dan $1,75 \sim 2 \%$ pada range pengujian antara $860 \sim 400 \mathrm{rpm}$.
\end{abstract}

Kata kunci : kecepatan pengelasan, pengelasan pipa, sistem kontrol

\section{ABSTRACT}

The Circular welding processes are often encountered in various manufacturing processes in the industrial production such as welding processes on the circular pipes frame, compressed tubes, distribution pipes and others. The manual circular welding process are often found welding defects, due to welding difficulties in the circular plane. To overcome this problem, it is necessary to make a workpiece turning tool in the validation process and the speed can be adjusted. The objective of research is to design and make control system of process sequence, speed and accuracy of the welding process termination in the pipe welding process. The research methodology is preseded by initial literature review, analysis of control system requirements, 
control system design, manufacturing and testing of tools. The result was welding aids on circular workpieces have been made successfully. Some manufacturing process parameters was displayed on the LCD. The welding speed of the workpiece on the LCD display compared to testing with a tacho meter has a percentage of errors ranging from $1.5 \sim 1.7 \%$ and $1.75 \sim 2 \%$ in the test range between $860 \sim 400 \mathrm{rpm}$.

Keywords: welding speed, pipe welding, control system.

\section{PENDAHULUAN}

Proses pengelasan melingkar banyak dijumpai pada proses manufaktur di dunia industri seperti proses pengelasan pada rangka berbentuk pipa, tabung tekan, pipa distribusi dan lain-lain. Proses pengelasan ini dapat dilakukan dengan dua cara yaitu benda kerja diam dan elektroda las bergerak melingkar, atau benda kerja berputar dan electrode las diam. Cara pertama banyak dijumpai pada pengelasan manual dimana operator las melakukan proses pengelasan pada benda circular yang diam. Pada proses ini sering kali ditemukan cacat las karena adanya kesulitan pengelasan pada bidang yang melingkar. Sebaliknya, cara kedua sangat efektif untuk mengatasi kesulitan pengelasan pada bidang melingkar ini, namun cara kedua ini membutuhkan alat bantu pemutar benda kerja yang dapat diatur kecepatannya.

Pengelasan dengan las Gas Metal Arc Welding (GMAW) sering dipakai pada jenis pengelasan melingkar. Hal ini disebabkan karena pada jenis pengelasan GMAW, pelindung lasan berupa gas sehingga pasca pengelasan tidak perlu adanya proses pembersihan terak dan hasil pengelasan tidak terdapat retakan [1]. Untuk menjaga kualitas hasil lasan, pengaturan urutan proses, pengatur kecepatan, pengatur welding holder dan ketepatan penghentian proses pengelasan sangat diperlukan.

Untuk mendesain suatu proses manufaktur agar beroperasi dengan baik maka perlu dipahami beberapa kaidah pengaturan. Beberapa jenis pengaturan dapat dilakukan dengan berbagai cara dan alat yang tersedia di lapangan antara lain mikro komputer, mikro kontroler, PLC, arduino dan lainlain. Para peneliti sebelumnya yang telah melakukan penelitian pengaturan urutan proses manufaktur antara lain Silvia[2], Kushartanto dkk [3] Huda dkk [4] dan Kabib[5]. Pada penelitian ini, pengaturan dengan arduino dipakai untuk mengatur urutan proses, penekanan holder las, dan akurasi penghentian proses pengelasan sehingga kualitas pengelasan dapat dijaga.

Penelitian ini bertujuan melakukan rancang bangun sistem kontrol urutan proses, kecepatan dan ketepatan penghentian proses pengelasan pada proses pengelasan pipa. Peralatan yang di rancang dan di buat sangat membantu dalam proses pengelasan pipa untuk mendapatkan kulitas pengelasan yang baik.

\section{METODOLOGI PENELITIAN}

Metodologi penelitian ini dimulai dengan kajian pustaka, analisa kebutuhan sistem kontrol, desain sistem kontrol dan pembuatan dan pengujian alat. Desain sistem kontrol meliputi penyusunan diagram block sistem, perancangan instalasi LCD, perancangan instalasi motor, perancangan instalasi servo dan perancangan instalasi sensor. Konsep desain dalam merancang sistem kontrol alat bantu pengelasan pipa ini meliputi beberapa mekanisme gerakan. Pengaturan putaran kecepatan motor bertujuan untuk mendapatkan gerakan berputar benda kerja sesuai kecepatan pengelasan yang diinginkan. Rangkaian rotary encoder dan tampilan LCD dipakai untuk pembacaan kecepatan putar dan ketepatan penghentian proses pengelasan secara otomatis. Sedangkan motor servo dipakai untuk menekan holder pengelasan. Rancangan desain alat bantu pengelasan dapat dilihat pada Gambar 1 . Pada Gambar 1 terlihat bahwa, peralatan yang didesain terdiri dari: 1). Motor DC, 2). Rangkaian rotary encoder, 3). Motor servo, 4). Panel box, dan 5. Power supply.

Prinsip kerja dari komponen-komponen tersebut adalah sebagai berikut : 
a. Motor DC dipakai sebagai penggerak utama mesin, dan dihubungkan dengan gerbox dengan ratio 60:1. Putaran poros keluaran gearbox selanjutnya ditransmisikan dengan menggunakan gear dan rantai ke poros pencekam benda kerja dengan ratio 4:1.

b. Rangkaian rotary encoder yang terdiri dari piringan berlubang, sensor cahaya dan lampu LED dipakai sebagai sensor pembacaan kecepatan pengelasan dan sistem berhenti otomatis pada mesin.

c. Motor servo dipakai untuk menekan holder las secara otomatis.

d. Panel box berisi beberapa komponen seperti: PWM speed control (dimmer), LCD dan tombol tekan. PWM speed control (dimmer) berfungsi untuk mengatur kecepatan motor, sedangkan LCD berfungsi untuk menampilkan mode-mode yang telah dibuat.

e. Power supply berfungsi sebagai tegangan utama untuk mengoprasikan mesin input power supply dengan tegangan $220 \mathrm{AC}$ dan outputnya $12 \mathrm{~V} \mathrm{DC}$.

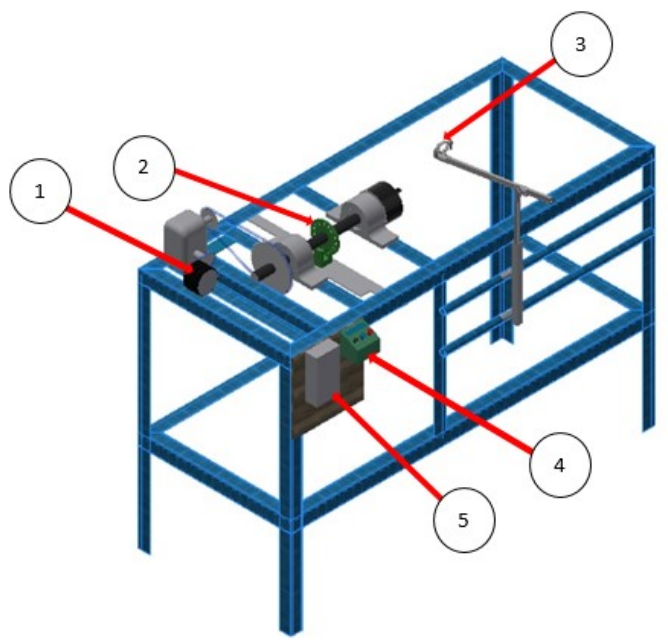

Gambar 1. Konsep desain sistem kontrol

\section{HASIL DAN PEMBAHASAN}

\subsection{Rangkaian Hardware Sistem Kontrol}

Hasil rancangan rangkaian hardware sistem kontrol dapat dilihat pada Gambar 2. Rangkaian hardware sistem kontrol berupa layout komponen dan diagram pengkabelan rangkaian kontrol. Pembuatan hardware pada sistem kontrol alat bantu pengelasan pipa ini menggunakan arduino sebagai kontroler, rangkaian rotary encoder, LCD, power supply, relay, dimmer, motor DC dan motor servo. 


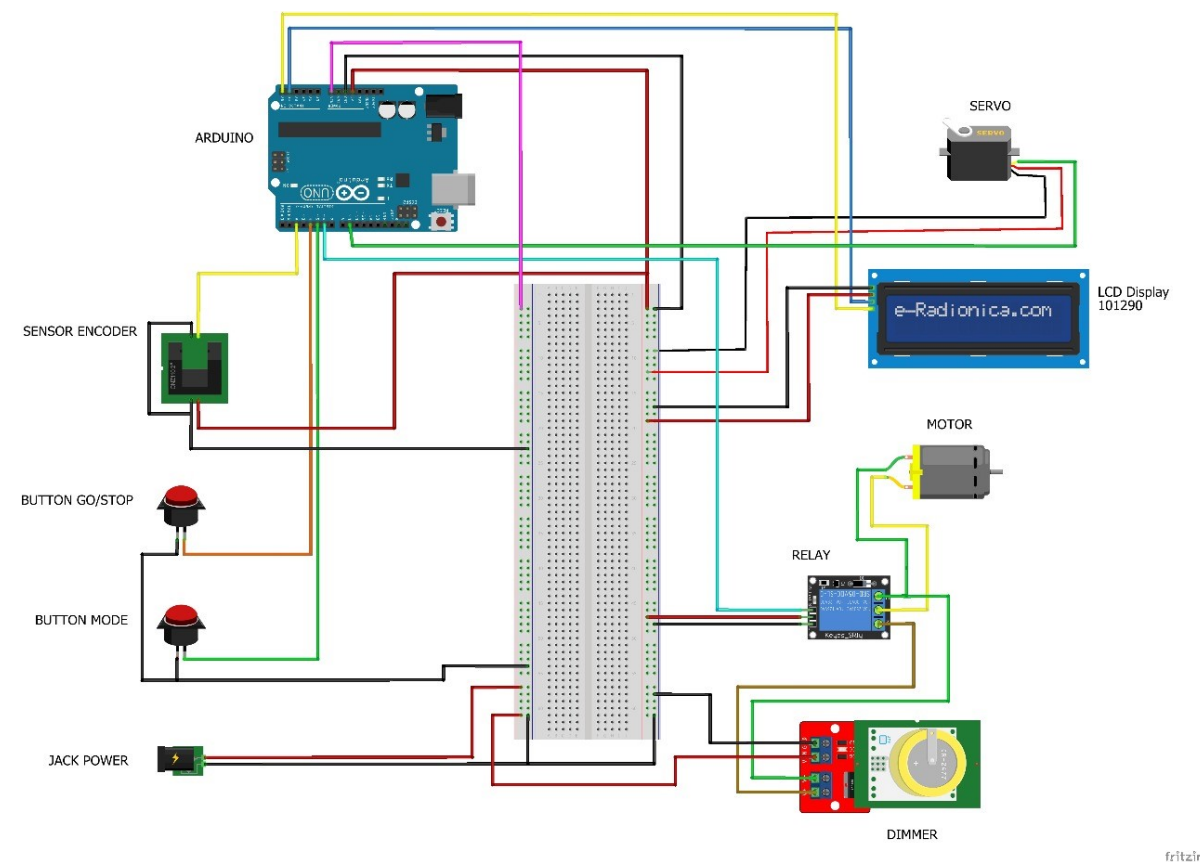

Gambar 2. Rangkaian Hardware Sistem Kontrol

Penjelasan dari rangkaian yang dapat dilihat pada Gambar 2 adalah sebagai berikut:

a. Arduino uno berfungsi sebagai komponen kontroler pengolah data dari komponen komponen linnya.

b. Jack power (power supply) sebagai sumber tegangan utama sebesar 12 vdc.

c. Dimmer berfungsi untuk mengatur kecpatan putar motor dc, dimmer terhubung ke relay dan motor dc.

d. Relay berfungsi sebagai saklar elektronik untuk menghentikan arus ke motor dc untuk sistem berhenti otomatis,relay terhubung ke pin 6 digital Arduino serta VCC relay ke pin 5v Arduino dan GND relay ke GND Arduino untuk outputnya menggunakan tegangan 12 vdc dari power supply pin NC dan pin GND pada relay dihubungkan ke motor DC.

e. Motor DC berfungsi sebagai penggerak utama dari mesin.

f. Motor servo berfungsi untuk menekan holder las secara otomatis,pin GND motor servo terhubung ke pin GND Arduino,pin vcc motor servo terhubung ke pin 5v Arduino, dan pin sinyal motor servo terhubung ke pin digital 9 Arduino.

g. Sensor encoder berfungsi untuk membaca jumlah lubang pada piringan yang diletakkan pada poros mesin yang berfungsi untuk menghentikan mesin secara otomatis, pin vcc sensor terhubung ke 5v Arduino,pin GND sensor terhubung ke pin GND Arduino,dan pin sinyal sensor terhubung ke pin digital 2 Arduino.

h. Button mode terdapat beberapa mode yang bisa dijalankan melalui button ini yaitu mode setting speed berfungsi mengatur kecepatan motor DC,mode seting count untuk menentukan jumlah lubang pada piringan yang akan digunakan dalam pengelasan,seting diameter pipa untuk memasukan diameter pipa yang akan di las.

i. Button $G O$ berfungsi untuk melakukan proses pengelasan ketika button go ditekan motor servo akan menekan holder las selang 2 detik motor dc hidup memutar pencekam dan menggerakkan pipa setelah pengelasan selesai mesin akan berhenti secara otomatis dan motor servo melepaskan tang las sehingga proses pengelasan berhenti.

j. LCD berfungsi untuk menampilkan berbagai mode yang telah di atur dalam Arduino, pin vec LCD dihubungkan dengan pin 5V Arduino, pin GND LCD dihubungkan ke pin GND 
Arduino, pin sda LCD dihungungkan ke pin sda Arduino, pin scl LCD dihubungkan ke pin scl Arduino.

\subsubsection{Proses perakitan hardware ke mesin}

Dalam merakit hardware sistem kontrol akan disesuaikan dengan desain instalasi hardware yang dapat dilihat pada Gambar 2 adapun langkah-langkahnya sebagai berikut:

a. Memasang sensor rotary encoder ke poros mesin

b. Memasang motor servo di pemegang holder.

c. Memasang motor DC ke rangka mesin.

d. Memasang kabel penghubung motor ke relay dan dimmer.

e. Memasang kabel sesuai dengan instalasi hardwareyang ada pada gambar 2

f. Memasang kabel penghubung dari motor servo,sensor rotary encoder dan relay ke Arduino.

g. Memasang kabel power supply ke relay dan dimmer.

h. Menghubungkan relay ke Arduino.

i. Setelah instalasi hardware terpasang selanjutnya mengupload program ke dalam Arduino untuk mengontrol semua komponen.

\subsection{Perancangan dan pembuatan Software Sistem Kontrol}

Proses pembuatan program sistem kontrol menggunakan software Arduino IDE, Arduino menggunakan pemprograman dengan Bahasa C, setiap program Arduino (biasa disebut sketch) mempunyai dua buah fungsi yang harus ada dalam setiap program yaitu:

a. Void setup () \{\}

Semua kode dalam kurung kurawal hanya akan dijalankan selama satu kali ketika program Arduino dijalankan untuk pertama kalinnya.

b. Void loop () \{\}Fungsi ini akan dijalankan setelah fungsi void setup selesai, setelah dijalankan satu kali fungsi ini akan dijalankan lagi, dan lagi secara terus menerus sampe sumber tegangan di matikan.

Dalam pembuatan software sistem kontrol terdapat beberapa mode untuk membantu proses pengelasan untuk berganti mode menggunakan button terdapat dua buton yaitu button go/stop dan button mode adapun mode yang ada dalam pemrograman yaitu:

a. Mode setting speed dalam mode ini berfungsi untuk mengatur kecepatan putar motor dengan cara menekan button dan mengarahkannya ke mode setting speed lalu menekan tombol go, setelah itu putar dimmer untuk mengatur putaran sesuai kebutuhan pengelasan.

b. Mode setting count mode ini berfungsi untuk menentukan jumlah lubang yang akan dibaca oleh sensor untuk proses berhenti otomatis, untuk seting count tekan button mode pilih setting count untuk menambah dan mengurangi jumlah count gunakan button go seting sesuai kebutuhan pengelasan.

c. Mode setting pipa mode ini untuk memasukkan diameter pipa yang akan di las, dengan cara menekan tombol mode pilih setting pipa lalu tekan button go untuk memilih diameter pipa sesuai dengan pipa yang akan di las.

d. Mode ready mode ini untuk proses pengelasan setelah semua mode kita setting sesuai kebutuhan untuk menjalankan mode ready tekan button mode pilih mode ready lalu tekan button go maka servo akan menekan holder lalu motor akan berputar menggerakkan pipa setelah pengelasan selesai servo akan melepas holder dan motor akan berhenti berputar.

Adapun detail penulisan program sistem kontrol menggunakan software Arduino IDE dan penjelasan tiap baris adalah sebagaimana di tunjukkan pada gambar 2 sampai 9 berikut : 


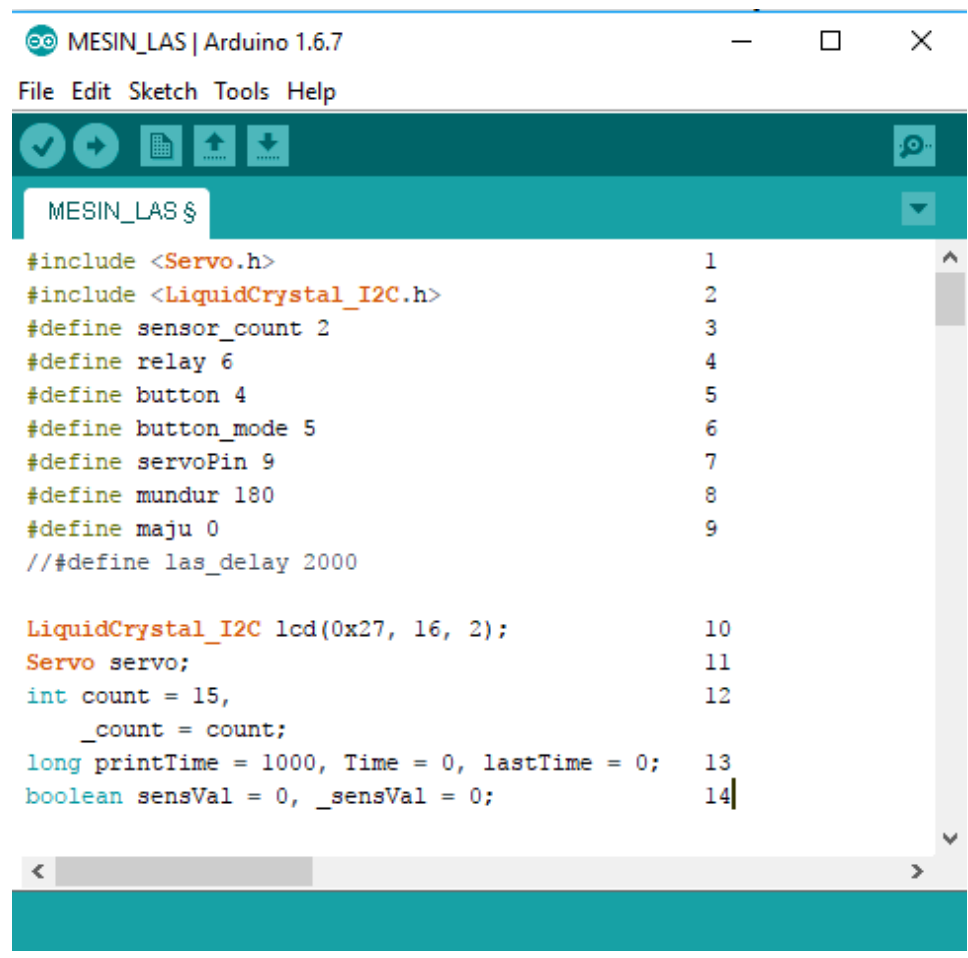

\section{Gambar 3. Deklarasi program}

Keterangan Gambar 3:

1. Memasukkan library servo.

2. Memasukkan library lcd dengan i2c.

3. Deklarasi sensor ke pin 2.

4. Deklarasi relay ke pin 6.

5. Deklarasi button ke pin 4 (untuk button go/stop).

6. Deklarasi button mode ke pin 5 (untuk button mode).

7. Deklarasi servo pin 9.

8. Variabel untuk derajat servo untuk mundur.

9. Variabel untuk derajat servo untuk maju.

10. Membuat variabel lcd(alamat i2c, jumplah baris led, jumplah kolom lcd).

11. Membuat variabel servo.

12. Deklarasi variabel count dan _count type integreter.

13. Deklarasi variabel time untuk waktu update led type data long.

14. Deklrasi variabel untuk sensor count type data Boolean. 


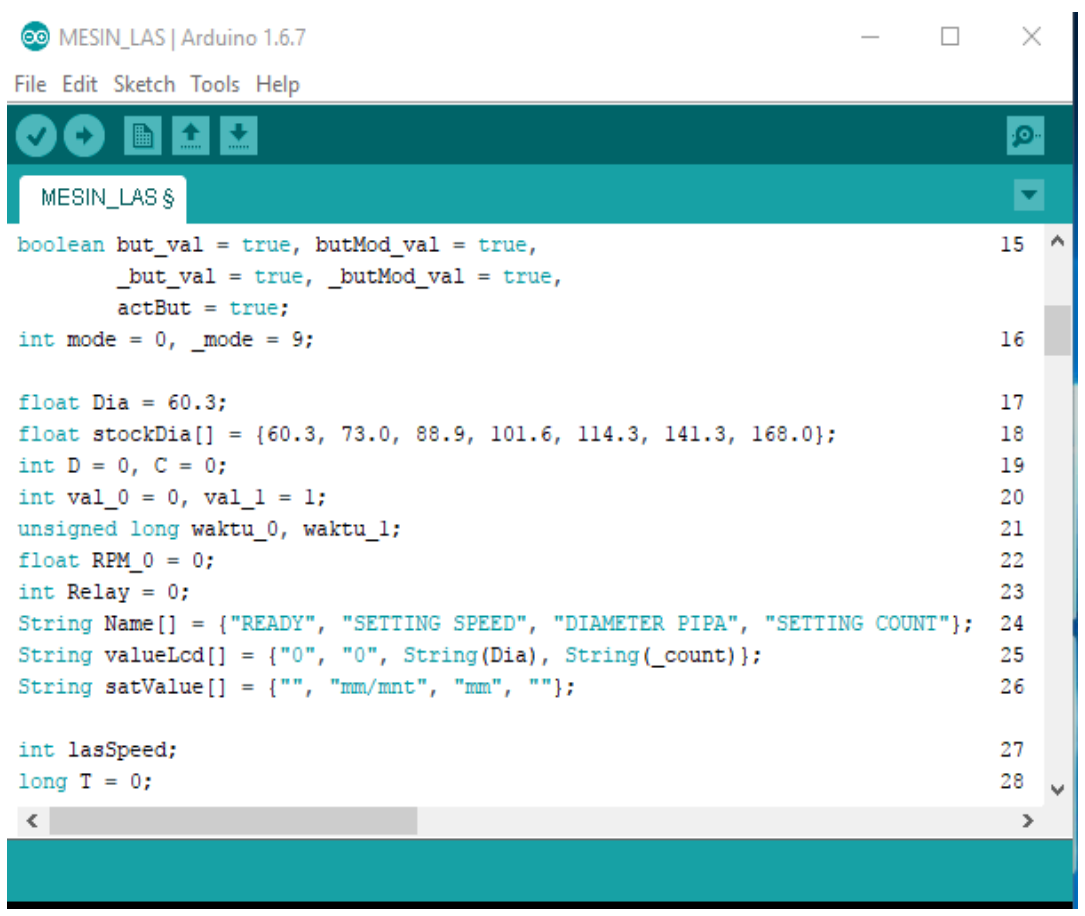

\section{Gambar 4. Deklarasi Mode pengelasan}

Keterangan Gambar 4:

15. Deklarasi variabel untuk button.

16. Mode 0: ready.

17. Deklarasi variabel diameter pipa.

18. Daftar stok diameter pipa.

19. Variabel untuk nomor diameter pipa dan nomor count.

20. Variabel sensor speed.

21. Variabel untuk waktu speed.

22. Deklarasi rpm.

23. Deklarasi untuk nilai relai $0=$ nylala, $1=$ mati.

24. Daftar variabel nama mode.

25. Daftar nilai mode.

26. Daftar satuan mode.

27. Variabel speed pegelasan.

28. Deklarasi T untuk selang waktu. 
Jurnal CRANKSHAFT, Vol. 2 No. 2 September 2019

ISSN: 2623-0720 (Print), 2623-0755 (Online)

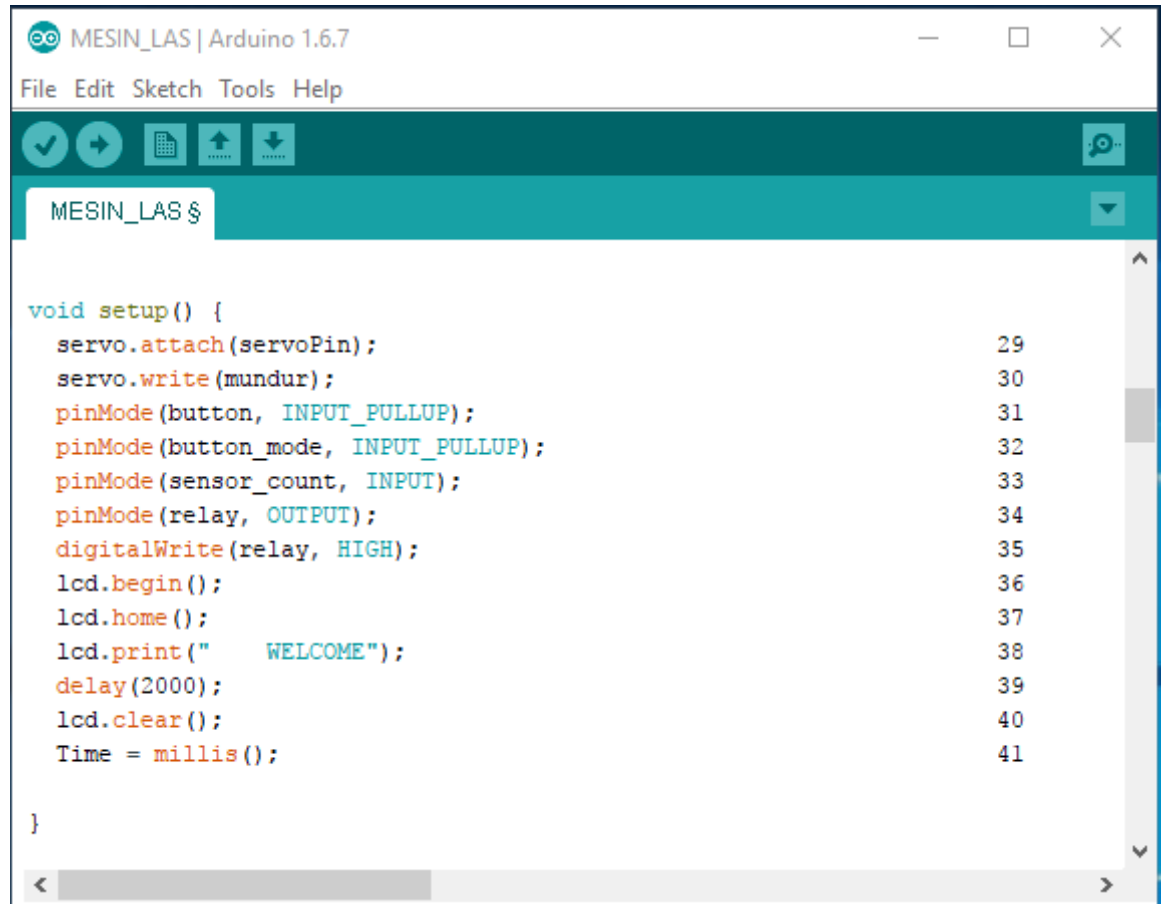

\section{Gambar 5. program void setup}

Keterangan Gambar 5:

29. Mengatur pin servo ke variable servo Pin.

30. Memundurkan servo agar las off pada awal dihidupkan.

31. Mengatur pin input.

32. Mengatur pin input.

33. Mengatur pin input untuk sensor.

34. Mengatur pin output untuk relay.

35. Mengatur relay HIGH(mati) untuk pertama kali dihidupkan.

36. Mulai mengaktifkan lcd.

37. Set cursor lcd ke home (baris 0 , kolom 0 ) mulai tulis dari posisi ini.

38. Menapilkan teks WELCOME di tengah.

39. Tunggu 2 detik.

40. Menghapus karakter di lcd

41. Menyamakan variabel Time $=$ millis () (waktu berjalan arduino) . 


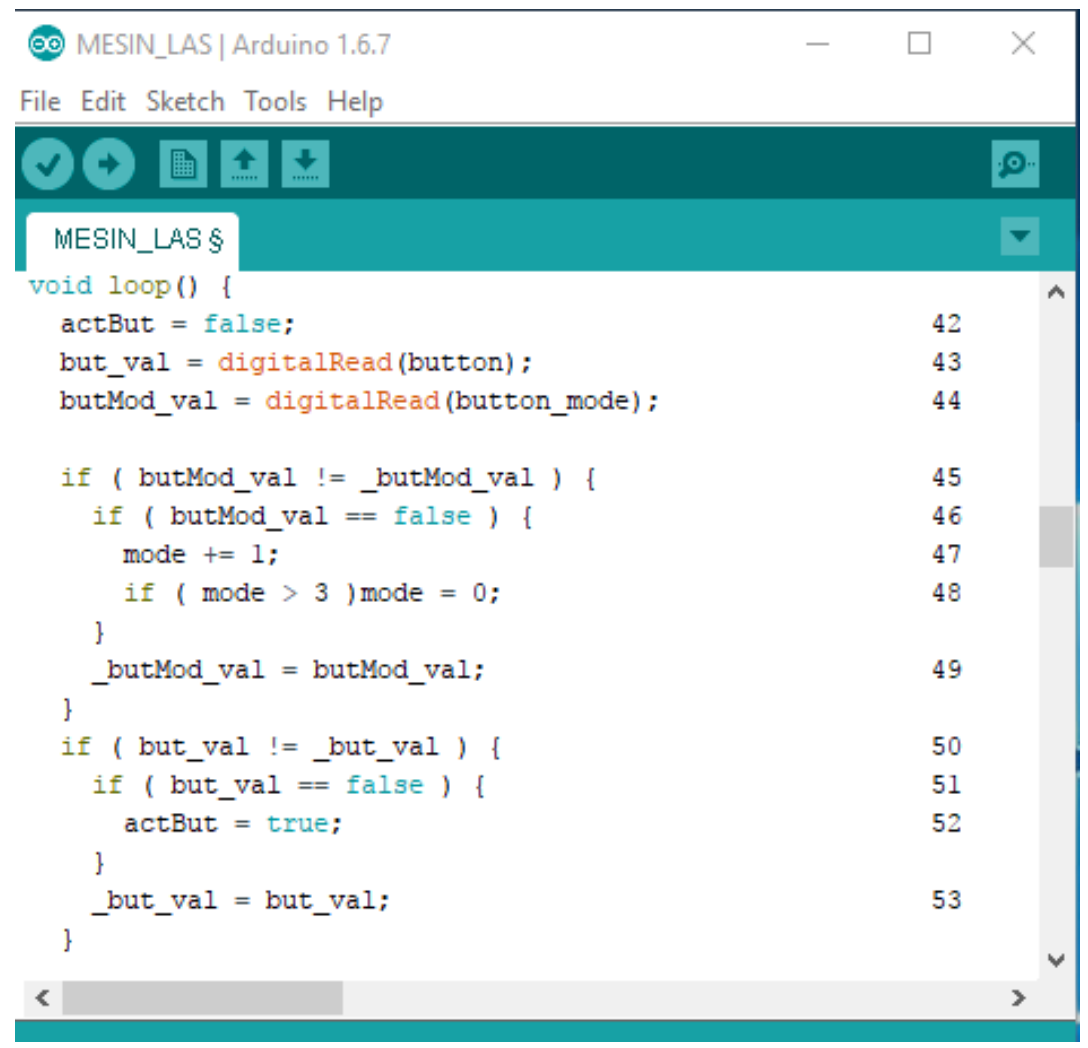

\section{Gambar 6. program void loop}

Keterangan Gambar 6:

42. Mengecek jika mode di ubah $>$ mode tadi tidak sama dengan mode sekarang.

43. Mengubah nilai but val = hasil baca sensor buton go/stop .

44. Mengubah nilai but $\mathrm{val}=$ hasil baca sensor buton mode.

45. Membandingkan hasil baca sensor button mode yang sekarang dengan yang sebelum nya.

46. Jika button ditekan atau di lepas.

47. Pindah mode.

48. Mengembalikan ke mode 0 jika mode $=4$ (mode 4 tidak ada).

49. Menyamakan value button mode tadi dengan sekarang.

50. Membandingkan hasil baca sensor button go/sto yang sekarang dengan yang sebelum nya.

51. Jika button ditekan atau di lepas.

52. Mengubah value actBut $=$ true $>$ tanda jika tombol go/stop ditekan.

53. Menyamakan value button go/stop tadi dengan sekarang. 


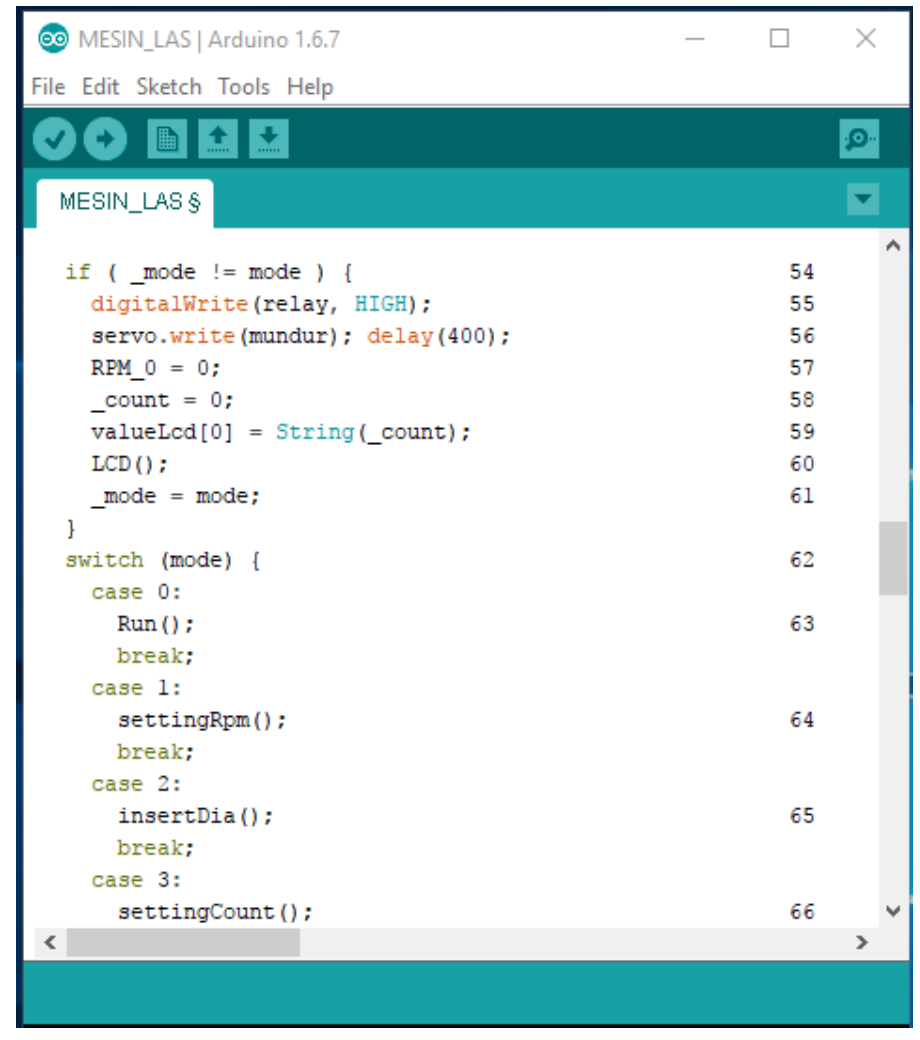

\section{Gambar 7. Pengecekan mode program}

Keterangan Gambar 7 :

54. Mengecek jika mode di ubah $>$ mode tadi tidak sama dengan mode sekarang.

55. Untuk menghindari eror karena mode di ubah ketika mesin jalan maka: mematikan relay motor.

56. Mematikan las.

57. Mengeset rpm ke 0 .

58. Mengembaikan count yang berjalan ke 0 .

59. Update data valueLcd ke $0=$ _count

60. Mengupdate led > note: progam lompat ke void LCD.

61. Mengubah nilai mode tadi sama denga ke mode sekarang.

62. Mengecek mode yg sedang di pakai.

63. Apabila mode $=0>$ maka progam pergi ke void RUN.

64. Apabila mode $=1>$ maka progam pergi ke void settingRpm.

65. Apabila mode $=2>$ maka progam pergi ke void insertDia.

66. Apabila mode $=3>$ maka progam pergi ke void settingCount. 


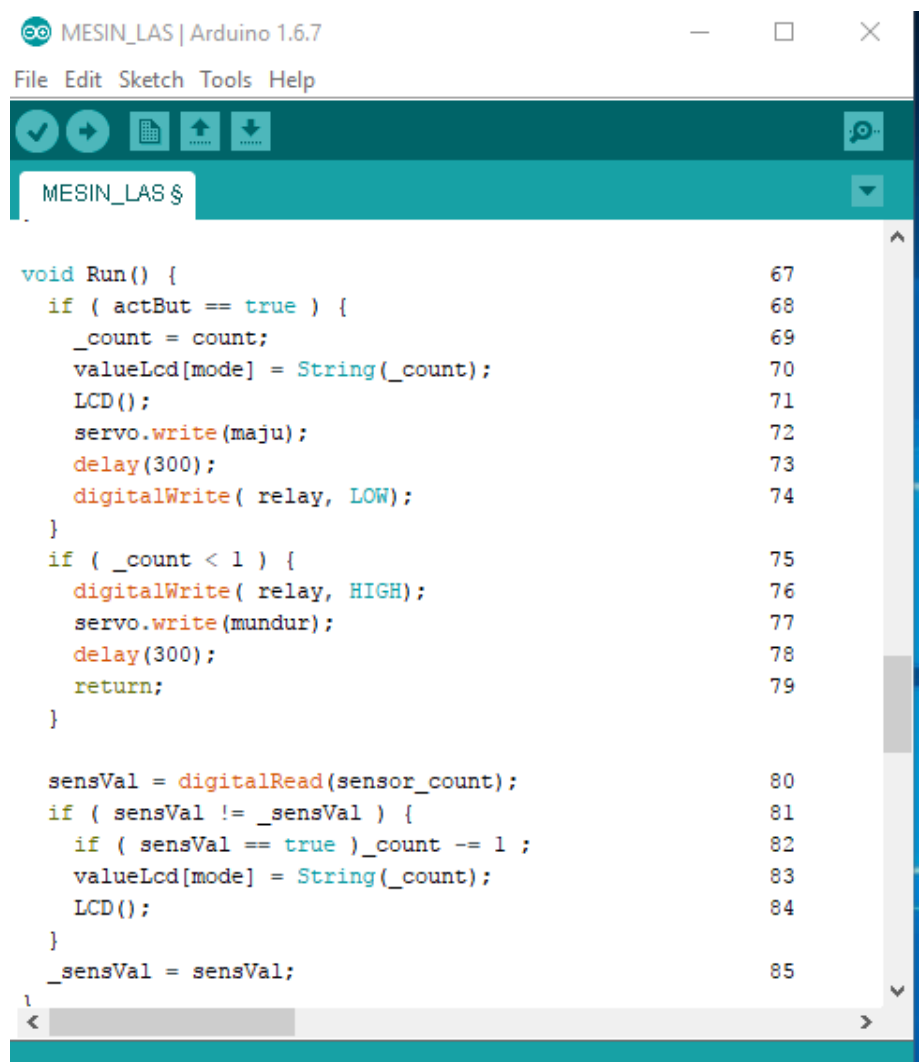

\section{Gambar 8. Program void run}

Keterangan Gambar 8:

67. Blok kode ready.

68. Jika tombol go/stop di tekan saat mode ready.

69. Menyamakan nilai_count dengan count yg di set.

70. Update valueLcd ke 0 sama dengan count $>$ artinya start putaran.

71. Update LCD.

72. Menggerakan servo untuk maju.

73. Menunggu servo sampai di tujuan.

74. Menghidpkan relay motor.

75. Cek jika count tercapai atau sudah 1 putaran as.

76. Mematikan relay motor.

77. Mundurkan servo.

78. Menunggu servo sampai di tujuan.

79. Progam kembal ke void loop.

80. Membaca sensor dan menaruh nilai di variabe sensVal.

81. Cek hasil baca sensor tida sama dengan sebelumnya true $>$ false false $>$ true.

82. Jika sensor true atau detected maka count di kurang 1.

83. Update valueLcd ke 0 dengan count (untuk print lcd).

84. Update lcd.

85. Mengubah value sensor tadi sama dengan sekarang. 


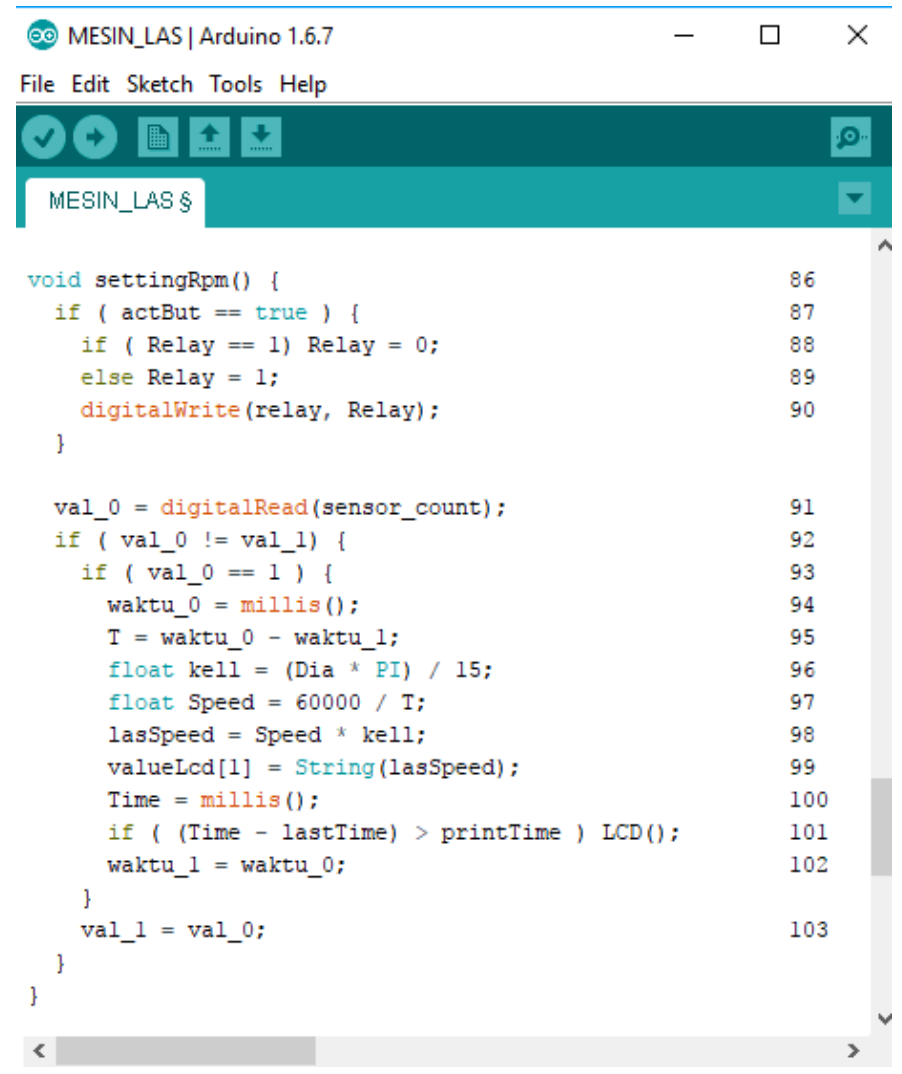

Keterangan Gambar 9:

\section{Gambar 9. Program setting rpm}

86. Blok kode setting rpm.

87. Cek jika tombol go/stop di tekan.

88. Jika value Relay sebelunya 0 maka valuenya di ubah menjadi 1

89. Jika tidak value di ubah ke 0

90. Mematikan atau menhidupkan relay sesuai value Relay jika sebelumnya hidup maka di matikan.

91. Membaca sensor dan menaru value di val 0 .

92. Jika hasil sensor tidak sama dengan sebelumnya; note: perubahan deteced dan tidak detected.

93. Jika sensor detected.

94. Menyamakan value variabel waktu_0 sama dengan waktu millis Arduino.

95. Menghitung jarak waktu detected sensor tadi dengan sekarang.

96. Menghitung jarak tempuh sisi pipa dalam 1/15 putaran.

97. Menghitung RPM poros.

98. Menghitung kecepatan tempuh sisi pipa $\mathrm{mm} /$ menit.

99. Update valueLcd ke 1 dengan hasil speed las.

100. Menyamakan variabel Time dengan waktu milis Arduino.

101. Cek jika sudah waktu update lcd;

102. Menyamakan waktu pembacaan sensor tadi dan sekarang, untuk digunakan pembacaan waktu selanjutnya.

103. Menyamakan value sensor tadi dengan sekarang. 


\subsection{Hasil Pengujian}

Pengujian dilakukan bertujuan untuk membandingkan pembacaan kecepatan pengelasan (Kecepatan putar benda kerja) dengan tachometer digital dan perhitungan secara manual. Pengujian dilakukan dengan variasi tiga kecepatan yang berbeda dan tiap kecepatan di uji sebanyak tiga kali.

\subsubsection{Tabel Perbandingan Kecepatan pada LCD dan Tachometer}

Perbandingan kecepatan pada pembacaan LCD dan tachometer (kontak) dapat dilihat dalam pada Tabel 1. Persentase kesalahan pembacaan kecepatan translasi pengelasan berkisar antara 1,58 s/d $1,7 \%$.

Tabel 1. perbandingan speed LCD dengan Tacho meter ( Kontak)

\begin{tabular}{cccccccc}
\hline NO & $\begin{array}{c}\text { Kecepatan } \\
\text { Pembacaan } \\
\text { LCD } \\
(\mathrm{mm} / \mathrm{min})\end{array}$ & $\begin{array}{c}\text { Kecepatan } \text { tachometer }(\mathrm{mm} / \mathrm{menit}) \\
\text { pertama }\end{array}$ & $\begin{array}{c}\text { Pengujian } \\
\text { kedua }\end{array}$ & $\begin{array}{c}\text { Pengujian } \\
\text { ketiga }\end{array}$ & $\begin{array}{c}\text { Rata- } \\
\text { rata }\end{array}$ & Penyimpangan & $\begin{array}{c}\text { Persentase } \\
\text { kesalahan }\end{array}$ \\
\hline 1 & 860 & 840 & 850 & 850 & 846,6 & 13,4 & $1,58 \%$ \\
2 & 620 & 610 & 600 & 620 & 610 & 10 & $1,6 \%$ \\
3 & 400 & 400 & 390 & 390 & 393,3 & 6,7 & $1,7 \%$ \\
\hline
\end{tabular}

\subsubsection{Tabel Perbandingan Speed LCD Dengan Perhitungan Manual}

Perbandingan pembacaan kecepatan LCD dengan perhitungan manual dapat dilihat dalam Table 2. Persentase kesalahan pembacaan kecepatan translasi pengelasan dengan perhitungan manual berkisar antara $1,75 \mathrm{~s} / \mathrm{d} 2 \%$

Tabel 2. Perbandingan speed LCD dengan Perhitungan manual

\begin{tabular}{cccccccc}
\hline NO & $\begin{array}{c}\text { Kecepatan } \\
\text { Pembacaan } \\
\text { LCD } \\
(\mathrm{mm} / \mathrm{min})\end{array}$ & \multicolumn{2}{c}{ Perhitungan manual (mm/menit) } & Pengujian \\
\cline { 3 - 5 } & pertama & $\begin{array}{c}\text { Pengujian } \\
\text { kedua }\end{array}$ & $\begin{array}{c}\text { Pengujian } \\
\text { ketiga }\end{array}$ & $\begin{array}{c}\text { Rata- } \\
\text { rata }\end{array}$ & Penyimpangan & $\begin{array}{c}\text { Persentase } \\
\text { kesalahan }\end{array}$ \\
\hline 1. & 860 & 843,6 & 847,4 & 844,8 & 845,2 & 14,8 & $1,75 \%$ \\
2. & 620 & 613 & 606 & 607,7 & 608,9 & 11,1 & $1,8 \%$ \\
3. & 400 & 395 & 390 & 391 & 392 & 8 & $2 \%$ \\
\hline
\end{tabular}

\section{KESIMPULAN}

Sistem pengaturan urutan proses, kecepatan pengelasan dan ketepatan penghentian pada alat bantu pengelasan pipa telah berhasil dirancang, dibuat dan diuji. Beberapa parameter proses manufaktur ditampilkan dalam LCD. Kecepatan pengelasan benda kerja pada tampilan LCD dibandingkan dengan pengujian dengan tacho meter mempunyai persentase kesalahan berturutturut berkisar $1,5 \sim 1,7 \%$ dan $1,75 \sim 2 \%$ pada range pengujian antara $860 \sim 400 \mathrm{rpm}$. 


\section{DAFTAR PUSTAKA}

[1] Sopian \& F.B. Susetyo, 2017, " Pengaruh Besar Sudut Kampuh Terhadap Kekuatan Tarik Hasil Pengelasan GMAW', Jurnal KajianTeknik Mesin, vol. 2, no. 2, pp. 99-105.

[2] Silvia, 2014, "Rancang Bangun Akses Kontrol Pintu Gerbang Berbasis Arduino Dan Android", Electrans, 2014, vol. 13, no. 1, pp. 1-10.

[3] P. Kushartanto, M. Kabib dan R.Winarso, 2019, "Sistem Kontrol Gerak Dan Perhitungan Produk Pada Mesin Pres dan Pemotong Kantong Plastik", Jurnal CRANKSHAFT, Vol. 2 No.1,

[4] S. Huda, M. Kabib dan R.Winarso, 2017," Desain Automatic Line Plastic Packing of Cake Berbasis Mikrokontroler Atmega 328", Prosiding SNATIF Ke -4.

[5] M. Kabib, 2008," Analisa dan Pengembangan Sistem Kontrol pada Mesin Automatic Feeding untuk Proses U Bending", Thesis, Program studi Teknik Mesin, Institut Teknologi Sepuluh Nopember. 